Віталій ТАЦІЕНКО,

orcid.org/0000-0003-3372-9765

кандидат історичних наук,

доиент кафедри історії України

Уманського державного педагогічного

університету імені Павла Тичини

(Україна, Умань)

tatsiyenko1990@ukr.net

\title{
ОСВІТНІЙ РІВЕНЬ ПАРАФІЯЛЬНОГО ДУХОВЕНСТВА КИЇВСЬКОЇ ЄПАРХІЇ НА ПОЧАТКУ ХХ СТ. (НА ПРИКЛАДІ УМАНСЬКОГО ПОВIТУ)
}

\begin{abstract}
У статті на прикладі Уманського повіту розглядається освітній рівень православного парафіяльного духовенства на початку XX cm. 3'ясовано, що абсолютна більшість протоісреїв та священиків мали повну семінарську освіту. Звернено увагу на вищий освітній рівень священнослужителів повітового міста. Більшість дияконів $і$ псаломників мали значно нижчий освітній иеен порівняно з священиками, адже отримували знання у духовних училищах, початкових світських навчальних закладах та домашню освіту, оскільки для їх служіння семінарський курс не був обов'язковим.

Ключові слова: парафіяльне духовенство, освіта, духовне училище, духовна семінарія, Уманський повіт, Київська спархія.
\end{abstract}

Vitaliy TATSIYENKO, Ph.D.(History), assistant professor at History of Ukraine Chair, Pavlo Tychyna Uman State Pedagogical University (Ukraine, Uman) tatsiyenko1990@ukr.net

\section{EDUCATIONAL LEVEL OF THE CLERGY IN KYIV EPARCHY IN EARLY 20 ${ }^{\text {TH }}$ CENTURY (AT THE EXAMPLE OF UMAN DISTRICT)}

The investigation of the Orthodox Church history, in particular, the theological education, the educational level of the clergy during the period when Ukrainian lands belonged to the Russian Empire is of important scientific and practical significance. The study of the regional aspects allows researchers to analyze local features and more clearly identify common trends. The main goal of the article is to highlight church education for clergy on the example of Uman district that had the biggest number of churches on its territory at that time.

In early $19^{\text {th }}$ century the educational level of the clergy remained at a rather low level. Only a quarter of the priests had theological education. Most of the priests received professional training taking part in public liturgies together with village priests. Consequently, in the first half of the $19^{\text {th }}$ century the Metropolitans considered raising the level of the clergy's education as the main tasks of their activity. The reform in 1808-1814 contributed to creation of a three-tier system of theological education in the Russian Empire and the obligatory admission of the clergy's children to educational institutions was introduced. It dramatically changed the attitude of clerics towards specialized education. In the middle of 1960s the diocesan administration stated the "sufficiency" of the clergy's education.

At the beginning of the $20^{\text {th }}$ century the absolute majority of archpriests and priests in Uman district had seminary education. The number of senior priests without specialized education was limited to several percent. Education qualifications of urban clerics when compared with rural ones were higher. In Uman there were 2 priests who received higher theological education. However, the overwhelming majority of the clergy did not want to continue their studies at the academy, since a seminary course was enough for them to be ordained. 
The percentage of deacons having secondary specialized education was rather small because such education was not mandatory for providing services at church. Education at theological schools was enough. At the same time, a significant percentage of deacons was trained in secular educational institutions. The level of sacristans' education was much lower than that of clergymen's. It is worth noting that less than a half of priests received education in theological schools (seminaries, colleges).

Thus, it was elicited that the absolute majority of archpriest and priests received theological education at swminaries. Most deacons and psalm readers had significantly lower educational qualifications as they studied at theological schools, elementary secular institutions or at home. The specialized education was not obligatory for them to provide religious services.

Key words: parish clergy, education, theological school, theological seminary, Uman district, Kyiv diocese.

Постановка проблеми. Дослідження питань історії Православної церкви, зокрема, духовної освіти, освітнього рівня духовенства в часи перебування українських земель під владою Російської імперії має важливе науково-пізнавальне і практичне значення. В сучасній Україні система освіти безперервно розвивається і для оцінки наших сьогоднішніх здобутків у освітній галузі важливим $є$ вивчення історичного досвіду. Дослідження регіональних аспектів дасть змогу проаналізувати місцеві особливості та більш чіткіше увиразнити загальні тенденції.

Аналіз досліджень. Сучасна українська історіографія приділяє питанням освіти різних станів українського соціуму, зокрема, православного духовенства в XIX - на початку XX ст., недостатню увагу. Освітній рівень парафіяльних священно- і церковнослужителів Російської імперії висвітлюється у грунтовних працях Г. Фріза (Freeze, 1983), Б. Міронова (Миронов, 2003), в межах українських єпархій - Г. Надтоки (Надтока, 1998), В. Меші (Меша, 2009). На рівні Уманського повіту окремі аспекти проблеми вивчала Т. Кузнець (Кузнець, 2006). Однак, на жаль, не всі сторони окресленої теми досліджені достатньо всебічно та грунтовно. Для аналізу освітнього цензу парафіяльних кліриків цінними є статистичні відомості «Пам'ятних книг Київської єпархії» (Памятная книжка, 1910), де міститься інформація про персональний склад причтів, їх вік, сімейний стан, матеріальне становище (розмір платні, забезпечення землею, житлом), нагороди тощо, а також і їх рівень освіти.

Метою статті $\epsilon$ висвітлення освітнього рівня православного парафіяльного духовенства Уманського повіту на початку XX ст. 
Виклад основного матеріалу. На початку XIX ст. освітній рівень духовенства залишався на досить низькому рівні. Свідченням того можуть слугувати дані про освіту священиків м. Києва та дев'яти повітів (крім Уманського, Чигиринського, Черкаського) Київської єпархії у 1800 р. 31140 священиків дев'яти повітів єпархії лише 268 отримали духовну освіту, що складало 23,5\%. Але 3 них у православних навчальних закладах - 104 священики (38,8\%). Більшість протопопів та священиків (164 особи або 61,2\%) здобували освіту у католицьких та уніатських навчальних закладах (Чеховский, 1905: 305-306). У цьому плані православне духовенство особливо поступалося римо- та греко-католицькому, яке мало значно вищий освітній ценз.

У перші десятиліття XIX ст. більшість священиків була т. зв. «псалтирниками», або «дячковськими богословами», оскільки отримувала професійну підготовку у сільського священно-, церковнослужителя. Наука зводилася до навчання читання і письма, співу та читання на кліросі, прислужування священику у вівтарі, ходіння 3 причтом по требах та практичних настанов про поводження священно-, церковнослужителя під час богослужіння. Таким чином, більшість духовенства не отримувала професійної освіти у духовних навчальних закладах, а здобувала підготовку в богослужбовій практиці. Але поступово такі клірики виходили за штат і до середини XIX ст. їх майже не залишилося, а вільні посади займали випускники семінарій (Крижановский, 1890: 507-508). Тому одне з провідних місць у діяльності митрополитів займала проблема підвищення рівня освіти духовенства.

За реформою 1808-1814 рр. в Російській імперії утворилася триступенева система духовної освіти та вводилось обов'язкове зарахування дітей кліриків до навчальних закладів. Вони поділялися на духовні училища, які давали початкову освіту, семінарії - середню та академії - вищу. Така система духовної освіти залишалася незмінною до кінця синодального періоду. У Київській єпархії вона складалася з п'яти чоловічих духовних училищ (Києво- 
Подільського, Києво-Софійського, Богуславського, Черкаського i Уманського), двох жіночих, семінарії та академії.

За «Положенням про способи покращення становища духовенства» від 6 грудня 1829 р., єпархіальні адміністрації зобов'язувалися призначати на священицькі посади як у містах, так і в селах випускників духовних семінарій та академій. У разі недостатньої кількості семінаристів для заміщення священнослужительських посад мали переводити їх з інших єпархій. Лише за відсутності кандидатів для отримання сану у власній та інших єпархіях дозволялося рукопокладати у священики осіб із незавершеною семінарською освітою, але відповідної поведінки, та не молодших за 30 років. Обумовлювалося, що випускники академій мали перевагу перед семінаристами (ЦДІАК. Ф. 127. Оп. 383. Спр. 247. Арк. 4), а відповідно до статуту семінарій, місця в єпархіях мали отримуватися тільки «за ступенями, за кожним розрядом учням семінарій присвоєним». Тому, без перебільшення, реформа різко змінила ставлення кліриків до професійної освіти. Якщо раніше духовенство не надто бажало ії здобувати, то в середині XIX ст. розуміло, що чим краща освіта, тим більші перспективи відкривались (Римский, 1999: 149150). Отримання освіти стало рівнозначним отриманню місця.

Безумовно, заходи церковного керівництва сприяли поступовому підвищенню професійного рівня парафіяльного духовенства. Так, у звіті благочинного 9-го округу Уманського повіту I. Комарницького за першу половину 1839 р., у віданні якого перебувало 14 церков, лише один паламар с. Полянецьке у читанні книг, співі, знанні церковного уставу мав відзнаку «малограмотний». Усі інші священно- та церковнослужителі округу оцінювались як «хорош», «исправен», «знающ» (ЦДІАК. Ф. 127. Оп. 702. Спр. 563. Арк.2).

Та все ж, попри заходи центральної та єпархіальної адміністрацій, значна частина духовенства на середину XIX ст. залишалася поза освітою. Наприклад, у Київській єпархії, за даними духовної консисторії, 24231252 православних священнослужителів, тобто кожен п'ятий, не мали взагалі ніякої 
освіти. Така ситуація була характерною і для інших єпархій Правобережжя (Крижанівський, Плохій, 1994: 264-265). Відсутність освіти у кліриків була причиною виключення їх 3 духовного стану. Так, у 1865 р. митрополит Арсеній (Москвін) наказав виключити всіх безмісних та безграмотних осіб, що старші за 15 років (Распоряжения, 1865: 89).

Поступово освіченість духовенства зростала. У звіті Св. Синоду про стан єпархії у 1865 р. митрополит зазначав, що священно- та церковнослужителі єпархії мають «достатній рівень освіти». Майже всі священики отримали семінарську освіту, причетники ж навчались у духовних училищах і нижчих класах семінарії (ЦДІАК. Ф. 127. Оп. 1023. Спр. 180. Арк. 3).

У звіті київського митрополита Св. Синодові про стан єпархії за 1875 р. відзначалося, що майже всі священики, за винятком 43, отримали повну освіту в духовній семінарії, а 30 з них мали академічну освіту. Також зазначалося, що в Київській єпархії була достатня кількість кандидатів на місця священиків та дияконів із випускників семінарії, яких у 1875 р. нараховувалось 88, а на місця псаломників вистачало претендентів із незавершеною семінарською освітою (ЦДІАК. Ф. 127. Оп. 1023. Спр. 84. Арк. 6-7).

Освітній рівень православного парафіяльного духовенства Уманщини у 1909 р. можна простежити за даними таблиці (Памятная книжка, 1910: 401452):

\begin{tabular}{|c|c|c|c|c|c|c|c|c|c|c|c|c|c|c|}
\hline & 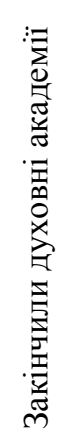 & 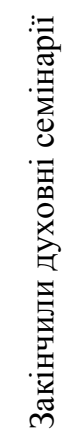 & 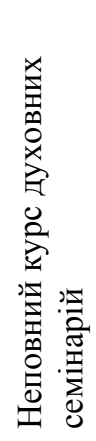 & 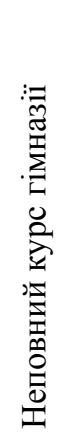 & 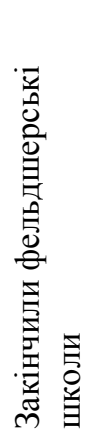 & 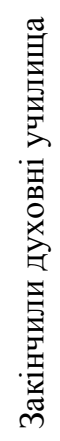 & 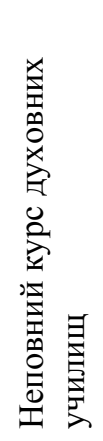 & 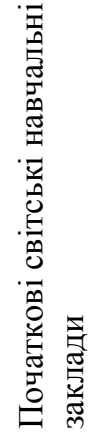 & 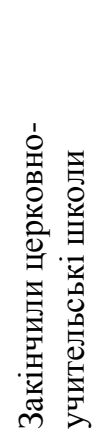 & 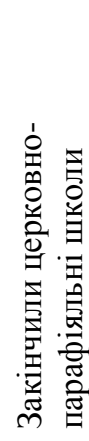 & 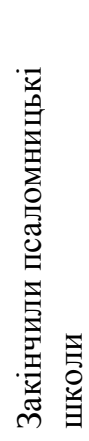 & 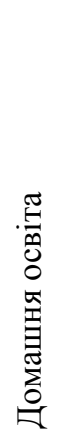 & 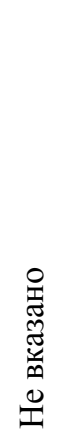 & $\frac{x}{0}$ \\
\hline $\begin{array}{l}\text { Протоієр } \\
\text { еї }\end{array}$ & & 3 & & & & & & & & & & & & 3 \\
\hline $\begin{array}{l}\text { Священи } \\
\text { ки }\end{array}$ & 2 & 140 & 2 & & & 2 & & & 1 & & & & & $\begin{array}{c}14 \\
7\end{array}$ \\
\hline Диякони & & & 2 & 1 & & 3 & 2 & 6 & & 1 & & 3 & 1 & 19 \\
\hline $\begin{array}{l}\text { Псаломн } \\
\text { ики }\end{array}$ & & 2 & 8 & & 1 & 21 & 19 & 31 & 2 & 13 & 1 & $\begin{array}{l}3 \\
3 \\
\end{array}$ & 6 & $\begin{array}{c}13 \\
7 \\
\end{array}$ \\
\hline
\end{tabular}




\begin{tabular}{|l|l|l|l|l|l|l|l|l|l|l|l|l|l|l|}
\hline Усix & 2 & 145 & 12 & 1 & 1 & 26 & 21 & 37 & 3 & 14 & 1 & $\begin{array}{c}3 \\
6\end{array}$ & $\begin{array}{c}30 \\
6\end{array}$ \\
\hline
\end{tabular}

3 наведених даних бачимо, що вищу духовну освіту в повіті мали 2 священики, що складало 1,3\% від загальної чисельності протоієреїв та священиків. Це настоятель Успенської соборної церкви Андрій Саббатовський та священик Михайлівської церкви при духовному училищі Василій Тростянський. Характерно, що це парохи, які служили в повітовому місті. Інформація по Уманському повіту зайвий раз підтверджує вищий освітній рівень міських священнослужителів. Зокрема, у жодній сільській парафії Уманщини на початку XX ст. не було священика, який би мав академічну освіту або хоча б незавершений курс вищого духовного навчального закладу. A iз 5 священиків м. Умань, які отримали середню духовну освіту, 4 завершили навчання за першим розрядом, 1 - за другим розрядом. Варто зауважити, що переважна більшість духовенства не бажала продовжувати навчання в академії, оскільки для отримання священицького сану цілком вистачало семінарського курсу. Академія готувала високоосвічених духовних

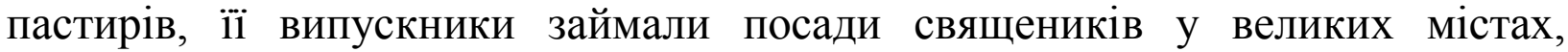
викладачів духовних навчальних закладів, кандидатів на вищі церковні посади. Сдиними місцями служби, на які обов’язково призначалися особи 3 вищою богословською освітою, були посади викладачів Київської академії та семінарії, законовчителів, священиків кафедрального собору (Калініч, 2008: $330)$.

Семінарську освіту мали 3 протоієреї та 140 священиків, що складало 95,4\%. 2 протоієреї та 38 священиків закінчили духовну семінарію за першим розрядом, 98 парохів - за другим розрядом (відсутня інформація щодо 1 протоієрея та 4 священиків). I лише 5 священиків $(3,3 \%)$ не мали середньої спеціальної освіти: 2 не осилили повного циклу семінарської науки (1 особа звільнена із 3 класу, 1 особа - із 5), 2 зупинились на духовних училищах, 1 навчався у церковно-учительській школі. Загалом, кількість протоієреїв та священиків з повною вищою та середньою освітою складала 145 осіб або 
96,7\%. Цікавим є той факт, що всі 7 священиків, які виконували обов'язки благочинних у повіті, отримали повну семінарську освіту за першим розрядом.

Попри недоліки семінарської освіти, все ж вона давала більш-менш пристойний загальноосвітній рівень. Адже значна частина випускників ставала не тільки священно- та церковнослужителями, а й працювала викладачами, ветеринарами, чиновниками, деякі продовжували здобувати освіту в університетах (Грекулов, 1969: 102).

Відсоток дияконів з середньою фаховою освітою був незначним, оскільки для проходження їх служби це не було обов'язковим. Вистачало освіти духовних училищ. У Київській єпархії станом на 1909 р. 3261 диякона лише 17 (6,5\%) мали семінарську освіту, 40 (15,3\%) - неповну. В Уманському повіті 318 дияконів (не враховуючи 1 особу, освіта якої не вказана) жоден не закінчив семінарію, 2 мали неповну середню духовну освіту, 3 закінчили духовні училища, 2 не завершили навчання у початковому духовному навчальному закладі. Всього в семінарії та училищі навчалось 7 осіб або $38,9 \%$. Водночас 8 дияконів (44,4\%) навчалось у світських закладах (1 мав не завершену гімназійну освіту, 6 здобуло освіту у початкових навчальних закладах, 1 - у церковнопарафіяльній школі). Домашню освіту отримали 3 диякони повіту (16,7\%).

Рівень освіти церковнослужителів був значно нижчим, ніж у священнослужителів. Варто відзначити, що попри вищий освітній ценз міських священиків у порівнянні з сільськими, освітній рівень псаломників міських храмів і сільських не відрізнявся. Чисельність церковнослужителів із повною семінарською освітою залишалася низькою і на початку XX століття. 31563 псаломників Київської єпархії 44 отримали повну середню спеціальну освіту, що складало 2,8\%. Характерно, що 17 із них служили у Києві, 2 - у повітових містах (Умані та Радомишлі), решта 25 - у сільських парафіях (К вопросу, 1903: 712). Найбільше псаломників Уманського повіту мали домашню освіту - 33 особи $(25,2 \%)$, початкову освіту світських навчальних закладів - 31 особа $(23,7 \%)$ та духовних училищах - 21 особа (16\%), не 
завершили навчання в духовних училищах 19 осіб (14,5\%), 13 псаломників (9,9\%) навчалося у церковнопарафіяльних школах. Повну семінарську освіту мали 2 церковнослужителі (1,5\%) - псаломники с. Криві Коліна Сергій Дусанський та с. Кищинці Антон Брояковський. 8 осіб $(6,1 \%)$ не завершили навчання у духовній семінарії. Окрім того, 2 псаломники закінчили церковноучительські школи, 1 - фельдшерську школу, 1 - псаломницьку школу. Відсутні відомості про освіту 6 псаломників. Варто зауважити, що всього здобували освіту у духовних навчальних закладах (семінарії, училищі, псаломницькій школі) менше половини церковнослужителів - 51 особа, що складало $38,9 \%$.

Станом на 1915 р. 3149 протоієреїв і священиків Уманщини (відсутні дані по церкві св. Марії Магдалини м. Умань) 1 протоієрей повітового міста отримав академічну освіту, 3 протоієреї та 138 священиків мали семінарську освіту, що загалом складало 95,3\%. Відповідно 7 священиків (4,7\%) не отримали середньої професійної освіти (ЦДІАК. Ф. 127. Оп. 1006. Спр. 176. Арк. 112-126).

Освітній рівень парафіяльного духовенства Уманського повіту цілком співвідносився з Київською єпархією на 1909 р., де кількість протоієреїв та священиків $з$ вищою та середньою освітою (враховуючи неповну) складала 1403 особи або 95,5 \%. Цей показник був дещо вищим, ніж у середньому по імперії, так як середньостатистичний становив майже $90 \%$ (Всеподданнейший отчет, 1911: 24-25, 28-29).

Висновки. Заходи світської влади і церковної адміністрації призвели до поступового підвищення освітнього та професійного рівня парафіяльних священно-, церковнослужителів, що дозволило єпархіальному керівництву на середину 60-х рр. ХІХ ст. констатувати «достатність» освіти духовенства. На початку XX ст. абсолютна більшість священиків Уманського повіту закінчили повний курс семінарської освіти. Священики, які не отримали середньої спеціальної освіти були радше винятком, адже їх чисельність обмежувалась кількома відсотками. Чітко простежується вищий освітній ценз міських 
священнослужителів порівняно з сільськими. 3 огляду на необов'язковість семінарської освіти для дияконів, переважна їх більшість мали початкову, причому здебільшого світську, а не духовну освіту. Псаломники мали різну освіту: третина навчалась у духовних училищах (враховуючи неповний курс), кожен четвертий отримав домашню освіту, майже стільки ж початкову у світських навчальних закладах. Така ситуація з освітою парафіяльних кліриків Уманського повіту на початку XX ст. була типовою і цілком співвідносилася з іншими церковно-адміністративними одиницями.

\section{Список використаних джерел і літератури}

Всеподданнейший отчет, 1911 - Всеподданнейший отчет оберпрокурора Святейшего Синода по ведомству православного исповедания за 1908-1909 годы. СПб., 1911. XVII, 663, 266 с.

Грекулов, 1969 - Грекулов Е. Ф. Церковь, самодержавие, народ (2-я половина XIX века - начало XX в.). М., 1969. 184 с.

К вопросу, 1903 - К вопросу об учреждении в Киевской епархии профессионального училища для детей местного духовенства // Киевские епархиальные ведомости. 1903. № 27. С. 710-713.

Калініч, 2008 - Калініч Г. Православне духовенство міста Києва наприкінці XIX - на початку XX ст.: зміни у соціально-професійній структурі // Просемінарій: Медієвістика. Історія Церкви, науки і культури. К., 2008. Вип. 7. C. 326-364.

Крижанівський, Плохій, 1994 - Крижанівський О. П., Плохій С. М. Історія церкви та релігійної думки в Україні: у 3 кн. К., 1994. Кн. 3: Кінець XVI - середина XIX століття. 336 с.

Крижановский, 1890 - Крыжановский Е. М. Украинская деревня второй четверти нынешнего столетия // Собрание сочинений: в 3 т. К., 1890. Т. I. C. $488-553$.

Кузнець, 2006 - Кузнець Т. В. Православне духовенство Уманщини XIX - початку XX століття. К., 2006. 607 с. 
Меша, 2009 - Меша В. Г. Конфесійний та суспільний аспекти розвитку православної церкви в Україні 1875 - 1900 років: Дис... д-ра іст. наук: 07.00 .01 / Донецький національний ун-т. Донецьк, 2009. 467 арк.

Миронов, 2003 - Миронов Б. Н. Социальная история России периода империи (XVIII - начало XX в.). СПб., 2003.: в 2 т. Т. 1.548 с.

Надтока, 1998 - Надтока Г. М. Православна церква в Україні 1900 - 1917 років: соціально-релігійний аспект. К., 1998. 271 с.

Памятная книжка, 1910 - Памятная книжка Киевской епархии на 1910 г. / Под ред. С. Трегубова. К., 1910. 552 с.

Распоряжения, 1865 - Распоряжения епархиального начальства // Киевские епархиальные ведомости. 1865. № 8. С. 89-90.

Римский, 1999 - Римский С. В. Российская церковь в эпоху великих реформ (Церковные реформы в России 1860 - 1870-х годов). М., 1999. 568 с.

ЦДІАК - Центральний державний історичний архів України.

Чеховский, 1905 - Чеховский В. Киевский митрополит Гавриил Банулеско-Бодони (1799-1803). К., 1905. 306 с.

Freeze, 1983 - Freeze G. The Parish Clergy in Nineteenth-Century Russia: Crisis, Reform, Counter-Reform. Princeton, 1983. XXXII, 507 p.

\section{REFERENCES}

Vsepoddannejshij otchet, 1911 - Vsepoddannejshij otchet ober-prokurora Svjatejshego Sinoda po vedomstvu pravoslavnogo ispovedanija za 1908-1909 gody. [All-embracing report of the Chief Prosecutor of the Holy Synod on the Office of the Orthodox Confession for the Period of 1908-1909]. SPb., 1911. XVII, 663, 266 s. [in Russian].

Grekulov, 1969 - Grekulov E. F. Cerkov', samoderzhavie, narod (2-ja polovina XIX veka - nachalo XX v.). [Church, autocracy, people (late $19^{\text {th }}$ century - early $20^{\text {th }}$ century)]. M., 1969. 184 c. [in Russian].

K voprosu, 1903 - K voprosu ob uchrezhdenii v Kievskoj eparhii professional'nogo uchilishha dlja detej mestnogo duhovenstva [On the establishment 
of vocational school for children of local clergy in Kyiv diocese] // Kievskie eparhial'nye vedomosti. 1903. № 27. S. 710-713. [in Russian].

Kalinich, 2008 - Kalinich H. Pravoslavne dukhovenstvo mista Kyieva naprykintsi XIX - na pochatku XX st.: zminy u sotsialno-profesiinii strukturi [The Orthodox clergy in Kyiv in late $19^{\text {th }}$ - early $20^{\text {th }}$ centuries: changes in social and professional spheres] // Proseminarii: Mediievistyka. Istoriia Tserkvy, nauky i kultury. K., 2008. Vyp. 7. S. 326-364. [in Ukrainian].

Kryzhanivskyi, Plokhii, 1994 - Kryzhanivskyi O. P., Plokhii S. M. Istoriia tserkvy ta relihiinoi dumky v Ukraini [History of church and religious issues in Ukraine]: u 3 kn. K., 1994. Kn. 3: Kinets XVI - seredyna XIX stolittia. 336 s. [in Ukrainian].

Krizhanovskij, 1890 - Kryzhanovskij E. M. Ukrainskaja derevnja vtoroj chetverti nyneshnego stoletija [Ukrainian village of the second quarter of this century] // Sobranie sochinenij: v 3 t. K., 1890. T. I. S. 488-553. [in Russian].

Kuznets, 2006 - Kuznets T. V. Pravoslavne dukhovenstvo Umanshchyny XIX - pochatku XX stolittia. [The Orthodox clergy in Uman region of $19^{\text {th }}-$ early $20^{\text {th }}$ centuries]. K., 2006. 607 s. [in Ukrainian].

Mesha, 2009 - Mesha V. H. Konfesiinyi ta suspilnyi aspekty rozvytku pravoslavnoi tserkvy v Ukraini 1875 - 1900 rokiv [Confessional and social aspects of the Orthodox Church development in Ukraine in 1875 - 1900]: Dys... d-ra ist. nauk: 07.00.01 / Donetskyi natsionalnyi un-t. Donetsk, 2009. 467 ark. [in Ukrainian].

Mironov, 2003 - Mironov B. N. Social'naja istorija Rossii perioda imperii (XVIII - nachalo XX v.). [Social history of the empire period in Russia $\left(18^{\text {th }}\right.$ - early $20^{\text {th }}$ century)]. SPb., 2003.: v 2 t. T. 1.548 s. [in Russian].

Nadtoka, 1998 - Nadtoka H. M. Pravoslavna tserkva v Ukraini 1900 - 1917 rokiv: sotsialno-relihiinyi aspekt. [The Orthodox Church in Ukraine in 1900 - 1917: social and religious aspects]. K., 1998. 271 s. [in Ukrainian]. 
Pamjatnaja knizhka, 1910 - Pamjatnaja knizhka Kievskoj eparhii na 1910 g. [The memorial book of the Kyiv diocese in 1910] / Pod red. S. Tregubova. K., 1910. 552 s. [in Russian].

Rasporjazhenija, 1865 - Rasporjazhenija eparhial'nogo nachal'stva [Orders of the Eparchy authorities] // Kievskie eparhial'nye vedomosti. 1865. № 8. S. 89-90. [in Russian].

Rimskij, 1999 - Rimskij S. V. Rossijskaja cerkov' v jepohu velikih reform (Cerkovnye reformy v Rossii 1860 - 1870-h godov). [Russian Church in the period of great reforms (church reforms in Russia in 1860 - 1870)]. M., 1999. 568 s. [in Russian].

TsDIAK - Tsentralnyi derzhavnyi istorychnyi arkhiv Ukrainy. [The Central State Historical Archive of Ukraine]. [in Russian].

Chehovskij, 1905 - Chehovskij V. Kievskij mitropolit Gavriil BanuleskoBodoni (1799-1803). [Kyiv Metropolitan Havryil Banulesko-Bodoni (1799-1803)]. K., 1905. 306 s. [in Russian].

Freeze, 1983 - Freeze G. The Parish Clergy in Nineteenth-Century Russia: Crisis, Reform, Counter-Reform. Princeton, 1983. XXXII, 507 p. [in English]. 